International Journal of Linguistics, Literature and Culture

Available online at https://sloap.org/journals/index.php/ijllc/

Vol. 5, No. 5, September 2019, pages: 55 62

ISSN: 2455-8028

https://doi.org/10.21744/ijllc.v5n5.740

\title{
Speech Act in Indonesian Language Teaching: An Ethnography Communication Study
}

Dewa Ayu Widiasri a

Made Budiarsa $^{b}$

Nengah Sudipa ${ }^{c}$

Made Sri Satyawati $^{\mathrm{d}}$

Article history:

Received: 27 March 2019

Accepted: 31 July 2019

Published: 14 September 2019

\section{Keywords:}

ethnography communication;

Indonesian language;

learning;

speech act;

teaching;

\section{Abstract}

The purpose of this study is to identify the verbal form and function of students' speech acts in the classroom, using the ethnographic approach Hymes communication in order to express the way they interact in class. Data was gained from the speech acts of students and teachers during the learning process. Furthermore, this study applied a qualitative descriptive approach. From the results of the study, it is found that the verbal form and function of directive speech acts in classroom were questioning, commanding, and advising.

2455-8028 ${ }^{\circledR}$ Copyright 2019. The Author. This is an open-access article under the CC BY-SA license (https://creativecommons.org/licenses/by-sa/4.0/) All rights reserved.

\section{Author correspondence:}

Dewa Ayu Widiasri,

IKIP Denpasar, Indonesia

Email address: dewaayuwidiasri1@gmail.com

\section{Introduction}

Language as a communication tool is used by teachers and students in a classroom and is presented during the teaching and learning process (Latupeirissa \& Sayd, 2019). Good teacher competence is needed to build the interaction of educators and students and improve the competence of educators in the learning process should be able to create learning activities in an interactive, inspiring, fun, challenging, motivating learners to participate actively, contextually and collaboratively, giving enough space to stimulate creativity and independence of students, and in accordance with the talents, interests, abilities, and physical and psychological development of students. The purpose

a IKIP PGRI Bali, Denpasar, Indonesia

${ }^{\mathrm{b}}$ Udayana University, Denpasar, Indonesia

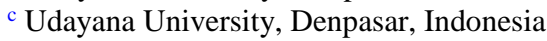

${ }^{\mathrm{d}}$ Udayana University, Denpasar, Indonesia 
of the above learning activities can be achieved with language acts, namely directive speech acts. The directive speech act is to stimulate student responses so that they participate more actively in classroom learning activities.

Related to the current research, that is about directive speech acts in classroom, there are 2 problems discussed, namely the form and function of verbal speech acts in classroom. The speech acts discussed in this study are speech acts used by speakers to get someone else to do something, another opinion states that directive speech acts are speech acts that aim to produce an effect that is done by the speaker (Leech \& Rayson, 2014; Djahimo et al., 2018; Suastini, 2016). The definition of speech acts above can be used as a parameter for conducting a study of teacher directive speech acts. In other words, the speech acts of teacher's speech can be categorized into directive tutu actions if the speech is used to order someone else. Speech can produce an effect. namely the act of speech. The following are several speech acts categories described by Searle (1969).

Searle (1969), divides speech acts based on pragmatic functions of language which include a representative or assertive speech commissive acts, speech directive acts, speech acts expressive, and speech acts declarative. Searle (1969), argues that speech acts representative are acts that serve to determine or explain what and how things happen as they are. For example giving statements, suggestions, reporting, complaints, and so on. Unlike the case with speech acts commissive, namely speech acts that have a function to encourage speakers to do something. Included in acts commissive themselves are swearing, promising, and submitting proposals. While speech acts are directive considered as speech acts that encourage listeners to do something. In addition to not being representative, commissive, and directive, there are also expressive acts, namely speech acts that are related to feelings and attitudes. These speech acts take the form of apologies, humor, praise, small talk, thanking, and so on. Expressive acts have a function to express the psychological attitude of the speaker towards the listener concerning certain circumstances. The last speech act grouped by Searle is a speech act declarative speech. Declarative acts are speech acts that connect the contents of the proposition with the actual reality. This speech act can be seen in the act of punishing, stipulating, firing, and giving names.

On the five speech act functions above, the matter that discussed in this study is directive speech acts because these speech acts are the most dominant and often used by teachers to stimulate students in the learning process. Besides, there were only view studies that were relevant to this research. First, a study entitled Divergent Principle of Politeness in Verbal and Nonverbal Directive Speech Act that was conducted by Lindayana et al., (2018). The purpose of the research was to describe the divergent principle of politeness in students' directive speech acts and factors that influence politeness and impoliteness in verbal and nonverbal directive speech acts produced by students at grade $\mathrm{X}$ in Senior High School 1 Mataram. The research used a qualitative descriptive approach. The data source was obtained from utterances that were spoken by students and teachers during the learning process. The results obtained by the single and multiple divergent principles of politeness affected by speakers intentionally accused addressees, intentionally uttered by neglecting the context, being protective to other arguments, showing emotional feelings, given critiques in impolite words and mocked at other.

Moreover, based on their research, it is stated that there are factors affecting politeness and impoliteness in verbal and nonverbal directive speech act produced by students in learning processes namely linguistic factors and nonlinguistic factors. The difference of their research and this current research is in the object of research study. Their research had the object of study in utterances that were produced by students at grade X in Senior High School 1 Mataram in the learning process in Indonesian, English, Economy, History, Math, Religion, Civic, and Science, and all students at Grade X of Science 1, Science 3 and Social 2 in Senior High School 1 Mataram, while in this study, the object of was only speech act that were taught by teachers during the teaching and learning process of Indonesian language in class IX.

Second, a study by Arani (2012); Suyanu et al., (2017); Azhari et al., (2018). She studied speech acts used by Iranian Nursery Schoolchildren as the impact of context on children's linguistic choices. The research aimed to find the form and function of the directive spoken by a Persian child. The writer's goal is to discover the distinct strategies applied by speakers of nursery school-age children regarding three parameters: the choice of form, the negotiation of communicative goals within the conversation, and the protection of the face. The data collected for this purpose are based on actual school conversational situations that were audio recorded in four nursery schools during classroom work and playtime activities. Children, who are the subjects of this study, are of both sexes and various social backgrounds. The results revealed that (1) the investigation of children's directive speech acts confirm the fact that they are aware of the social parameters of talk (Andersen-Slosberg, 1990; Ervin, Tripp et al., 1990), (2) they use linguistic forms that are different from what is used by adults as politeness markers, such as, poly the 2nd plural subject-agreement on the verb, "please" and "thank you" words; (3) They use declarative with illocutionary forces in order to mark support (Georgalidou, 2001; Iswanto et al., 2018; Prasetyo, 2017; Lindayana et al., 2018). There are 
similarities and differences in research. The research equation lies in pragmatic theory and data sources that are taught by students and teachers during the learning process. The difference lies in the object of study, namely Ariani (2012), focusing on the form and function of directives, especially the linguistic form and Illocutionary force, while the object of study in this study is the form and function of verbal speech acts influenced by the context of the utterances in the class .

Third, a study entitled directive speech act in the movie 'sleeping beauty' by Muhartoyo \& Kristiani (2013). Their research aims to identify the acts of words that occur in the film Sleeping Beauty. Furthermore, the study aims to find out how often the directive word acts occur and the types of word activities that are most often used in films. Their research used qualitative methods with data obtained from watching films, analyzing gestures and dialogues of the characters of players, reading scripts, and literature. There were 139 directive acts said successfully identified. The analysis shows that the ordering directive speaking is the most frequently used in films (21.6\%). While the inviting directive speaking was the least used $(0.7 \%)$. The research also found the importance of directive word actions in maintaining the storyline. The research was expected to provide a useful understanding of the directives said actions. There are similarities and differences between the research and the current study. The equation lies in the use of pragmatic theory together using directive functions. The research of Muhartoyo \& Kristiani (2013), was based on the data that was obtained from a conversation in the film titled sleeping beauty, while the current research was based on the data that was obtained from interactions in the classroom during the teaching and learning process.

\section{Materials and Methods}

The current research used a qualitative descriptive approach. The current research can be categorized as qualitative research because the purpose of this study is to produce descriptive data about the directive speech acts of Tampaksiring Bali High School I teachers. This is in line with Bungin (2007), that description data is generated to describe, summarize various conditions, various situations, or various reality phenomena that occur in society. Researchers chose this method to collect data in the form of words that were previously transcribed into written data based on the speech acts of the Indonesian language teacher directive at Tampaksiring I High School, Bali.

The data of this research is the Indonesian teacher's directive speech. as a source of data in this study is the utterance in the teaching and learning process in SMA I Tampaksiring, Bali class X. Data collection techniques used are the technique of recording and competent techniques. A recording technique, which records all the speeches of Indonesian teachers during the teaching and learning process taking place at SMA I Tampaksiring, Bali. The notetaking technique is used to record data containing teacher directive utterances during the teaching and learning process. After the data is collected, the ama data can be analyzed by the following procedure. (1) speech obtained through recording is played back and transcribed into written data during the teaching and learning process. (2) identifying data containing teacher directive utterances, (3) sorting, grouping, and dividing directive speech acts used by Indonesian teachers in Tampaksiring I High School, Bali. (4) Analyzing data based on the form and function of directive speech acts, and (5) Making data conclusions based on the results of the discussion of data analysis.

\section{Results and Discussions}

\section{Forms of Teacher Speech Actions in the Teaching and Learning Process}

After the data was collected and analyzed, there were found three most dominant directive utterances, namely questioning, commanding, and advising. The statement was based on the following data that describes conversation between teacher and student.

$\begin{array}{lll}\text { Teacher } & : & \text { There are types of books Who knows the definition of a } \\ \text { Student } & : & \text { Fiction and non-fiction } \\ \text { Teacher } & : & \text { What is fiction? } \\ \text { Student } & : & \text { True story } \\ \text { Teacher } & : & \text { Think again }\end{array}$

[Speech 1]

Widiasri, D. A., Budiarsa, M., Sudipa, I. N., \& Satyawati, M. S. (2019). Speech act in Indonesian language teaching: an ethnography communication study. International Journal of Linguistics, Literature and Culture, 5(5), 55-62. https://doi.org/10.21744/ijllc.v5n5.740 
The data (speech 1) was found in class X 3 IPS 1. It was held by teacher and student. It occurred when the teacher explained Indonesian learning material about book reviews and the teacher encouraged students to answer questions from the teacher about a type of reviewer. The teacher could stimulate students by asking students to participate actively in the learning process. However, the student was not ready to answer the questions and answered wrongly. Therefore, the teacher asked student to think again.

In the form of questioning speech in 'Speech 1' above, it was found that the speech act was obtained by questioning students to answer questions from the teacher. This request function shows an expression of the teacher's desire to take action in order to answer questions from the teacher about the type of book reviewing. Expressions of teacher desires could be conveyed well because students were encouraged by actively participating in answering questions from the teacher. However, students were not ready to answer the questions correctly. The readiness of students in teaching is a part of the preparation of teacher (preparing teaching material). At the beginning of learning, the teacher, actually, could give students time to read the material to be taught beforehand so that students could understand, answer, and actively participate in questions and answers or discussion in class.

The end purpose and goal of Speech 1 aimed to ask students to answer questions from the teacher, that is about the type of book reviews so that students can actively participate in class. Act sequence in data 1 above, namely students was asked to answer questions from the teacher about book reviews so that they are better prepared to receive teaching materials for book reviews in learning Indonesian. The key of teachers, in delivering teaching material about book reviews was delivering it with pleasure and clarity so that students can absorb the material well. Instrumental used by teachers to students in the oral pathway to comply with the norm in the learning interactions in the classroom. The genre delivered by the teacher was in the form of narration in the form of an explanation of the definition of the reviewer, type of reviewer, manner of review, and group assignment in a book review.

Next, following is the data of speech 2 that was based to describe another findings.

$\begin{array}{lll}\text { Teacher } & : & \text { Who still remembers about reviewing book? } \\ \text { Student } & : & \text { To pros and cons of a work } \\ \text { teacher's } & : & \text { What is the purpose of making a review? } \\ \text { Student } & : & \text { Reader } \\ \text { Teacher's } & : & \text { Good }\end{array}$

[Speech 2]

The conversation was held in class X 3 IPS 4 . When the teacher explained the book review in class, the teacher encourages students to answer questions. It is intended that students take an active role in the teaching and learning process. Furthermore, from speech 2 above it also appears that the teacher was seen actively giving material about book reviews while students look silent and listening when the teacher explains teaching material about the reviewer. Explain Indonesian learning material about book reviews and teachers encourage students. After that, students are instructed to form a small group to make a review and present the results of their group work review to the class. After they present the results of the group's work on the reviewer, then the other groups are given time to provide responses and questions on the group's work on reviewing an online game article.

Based on the results of the verbal form and verbal speech function of speech 2, it is stated that the verbal form of directive command has appeared as a function of communication. The command function indicates that the teacher's instructions are instructed by instructing students to make small groups and do the assignment given by the teacher about the reviewer. The expression of the teacher's desire to instruct students to take action is manifested by students forming small groups and making book reviews with their respective groups. In the beginning, the teacher seemed to need a long time to explain teaching material about book reviews to students. Students did not seem to participate much actively in responding to the teacher giving teaching materials in the Indonesian language. It is expected that the material delivered is concise, concise, and clear about book reviews and teachers focus more on students to improve student reading literacy about the reviewer. After that, the teacher engages students more with their groups to discuss and make book reviews.

The end purpose and goals of data 2 have the goal of having students create small groups and work on assignments about book reviews. Act sequences are students who are instructed to make reviews according to groups that have been previously divided by the teacher to better maximize the participation of other students in making reviews. Key teachers in delivering material seriously and too long so that students are quiet and do not play an active role in class. The instrumentalists used by the teacher are students, namely the oral path and LCD media in the form of Microsoft word to students so that the material delivered is clearer. Students obey the norm or norms of the 
teacher's commands by forming small groups and doing assignments about book reviews. The genre presented by the teacher is a narrative form in the form of an explanation of the meaning of the reviewer, the purpose of making the reviewer, and the task of the group looking for a reviewer.

\section{Counseling Speech Acts}

Counseling speech acts are speech that is done to advise or remind the interlocutor, in this case, to remind students about something the students have to do. The following is the data (speech 3 ) that shows counseling speech acts.

Teacher : Writing reviews should be done in groups

Students : Ok Mom

[Speech 3]

The above conversation was held in class X 3 IPS 3. It happened when the teacher explained about book reviews in class, and the teacher advised students to write reviews in groups. Speech markers advise 'should'. Speech 3 is an advising speech with an advising marker, which is best. A marker should remind students to work on book reviews in groups. This aims to stimulate students to actively participate in groups in working on assignments given by the teacher.

After the teaching and learning process is passed in the classroom, the teacher evaluates students to participate actively in working on group assignments. This was conducted by the teacher so students will understand better in order to answer questions from the teacher (about the reviewer and answer the teacher's questions).

By advising students to make small groups after the teaching and learning process, students can measure their ability to understand the material given about book reviews. After the review is made in the form of groups, the results of the review are collected to the teacher concerned. After that, the review results are presented in front of the class following the group and predetermined material. During the presentation, other groups are expected to hear and listen to the results of the review of the material provided. After the presentation is finished, the other groups can provide comments or suggestions to the results of the presentation that have been presented in front of the class.

In the explanation above, it is clear that the verbal form and verbal speech function of speech 3 , namely the verbal form of the directive advising function. The counseling function can identify that speech advises the teacher to students. Based on the results of the verbal form and verbal speech function of speech 3, obtained the verbal form directive function advising. The advisory function illustrates that the teacher's words advise students by advising them to make groups in small. After the groups are formed, each group works on a group review. The teacher's expression in advising students to create groups rather than individuals. During the teaching and learning process, students have not actively participated in the process. Therefore, the teacher advises students to create groups to actively participate in each other with other students. This aims to stimulate students' abilities in making book reviews.

In addition to creating groups in the classroom, students' reading culture is still low, this is evidenced by the lack of student involvement in class. This is one of the factors causing teachers to advise students to create groups so that their abilities are explored in making book reviews that have been determined. That way, one group can participate with each other and respond to the book review results.

The end purpose and goal of data 3 is to advise students to create groups so that students can actively participate in working on book reviews. Act sequences are students advised by the teacher to make review assignments according to groups that have been divided. This group aims to stimulate and motivate students so that reciprocal response relationships occur not only between teachers and students but also with students and other groups. In order to make reviews according to groups that have been previously divided by the teacher to better maximize the participation of other students in making reviews. Key students are quite a lot when the learning process takes place so the teacher advises students to make small groups. This is done by the teacher so that students actively participate in making assignments about book reviews. The instrumentalists that teachers use on students, namely the verbal pathway of students, make students more silent on the material presented. Students obey the norm or norms of the teacher's commands by forming small groups and doing assignments about book reviews. The genre presented by the teacher is a narrative form in the form of an explanation of the meaning of the reviewer, the purpose of making the reviewer, and the task of the group looking for a reviewer.

Widiasri, D. A., Budiarsa, M., Sudipa, I. N., \& Satyawati, M. S. (2019). Speech act in Indonesian language teaching: an ethnography communication study. International Journal of Linguistics, Literature and Culture, 5(5), 55-62. https://doi.org/10.21744/ijllc.v5n5.740 


\section{Conclusion}

Based on the results of the discussion above, there are several conclusions made. First, from the five types of pragmatic functions, directive function occurred dominant in the speech act of language teaching in Indonesia. The directive speech acts are used in the form of statements. Second, the verbal form of the directive function has been found in questions, while the verbal form of the directive function has been found in commanding and advising. Third, all speech acts are influenced by the context of the text.

\section{Conflict of interest statement}

The authors declared that they have no competing interest.

\section{Statement of authorship}

The authors have a responsibility for the conception and design of the study. The authors have approved the final article.

\section{Acknowledgments}

The current research was funded by $L P D P$ Indonesia. Therefore, the author would like to offer their gratitude to the government of Indonesia, in this case, LPDP. 


\section{References}

Andersen, O. (1990). U.S. Patent No. 4,919,618. Washington, DC: U.S. Patent and Trademark Office.

Arani, S. S. (2012). A study of directive speech acts used by Iranian nursery school children: The impact of context on children's linguistic choices. International Journal of Applied Linguistics and English Literature, 1(5), 163175. http://dx.doi.org/10.7575/ijalel.v.1n.5p.163

Azhari, A. S., Priono, -, \& Nuriadi, -. (2018). Speech Acts of Classroom Interaction. International Journal of Linguistics, Literature and Culture, 4(2), 24-45.

Bungin, B. (2007). Qualitative Research: Communication, Economics. Public Policy, and Other Social Sciences. Jakarta: Kencana.

Djahimo, S., Bili Bora, D., \& Huan, E. (2018). Student anxiety and their speaking performance: teaching EFL to Indonesian student. International Journal of Social Sciences and Humanities, 2(3), 187-195. https://doi.org/10.29332/ijssh.v2n3.235

Ervin-Tripp, S., Guo, J., \& Lampert, M. (1990). Politeness and persuasion in children's control acts. Journal of pragmatics, 14(2), 307-331. https://doi.org/10.1016/0378-2166(90)90085-R

Georgalidou, M. (2001). Pragmatic Parameters in Language Acquisition. The Directive Function. Unpublished Ph. D. Dissertation, University of Athens, Athens.

Iswanto, -, Riana, I. K., Simpen, I. W., \& Ola, S. S. (2018). Supernatural signification system amuf on death ritual speech nen fen nahat neu nitu in boti society. International Journal of Linguistics, Literature and Culture, 4(2), 46-57.

Latupeirissa, D. S., \& Sayd, A. I. (2019). Grammatical errors of writing in EFL class. International journal of linguistics, literature and culture, 5(2), 1-12. https://doi.org/10.21744/ijllc.v5n2.605

Leech, G., \& Rayson, P. (2014). Word frequencies in written and spoken English: Based on the British National Corpus. Routledge.

Lindayana, -, Arifuddin, -, \& Mandala, H. (2018). Divergent Principles of Politeness in Verbal and Non-Verbal Directive Speech Act. International Research Journal of Engineering, IT \& Scientific Research, 4(2), 41-51.

Mandala, H. (2018). Divergent Principles of Politeness in Verbal and Non-Verbal Directive Speech Act. International research journal of engineering, IT \& scientific research, 4(2), 41-51.

Muhartoyo, M., \& Kristani, K. (2013). Directive Speech Act in The Movie "Sleeping Beauty". Humaniora, 4(2), 949-966. https://doi.org/10.21512/humaniora.v4i2.3536

Prasetyo, H. (2017). Euphemism in oral dialect speech ngeto-ngete district suralaga. International Journal of Linguistics, Literature and Culture, 3(1), 65-74.

Searle, J. R., \& Searle, J. R. (1969). Speech acts: An essay in the philosophy of language (Vol. 626). Cambridge university press.

Suastini, N. W. (2016). The translation of English it-cleft sentences into Indonesian. International Journal of Linguistics, Literature and Culture, 2(4), 97-103.

Suyanu, -, Rusdiawan, -, \& Sumerep, A. Z. (2017). The use of language elements in the creation of coherences in discourse. International Journal of Linguistics, Literature and Culture, 3(5), 101-108.

Widiasri, D. A., Budiarsa, M., Sudipa, I. N., \& Satyawati, M. S. (2019). Speech act in Indonesian language teaching: an ethnography communication study. International Journal of Linguistics, Literature and Culture, 5(5), 55-62. https://doi.org/10.21744/ijllc.v5n5.740 


\section{Biography of Authors}

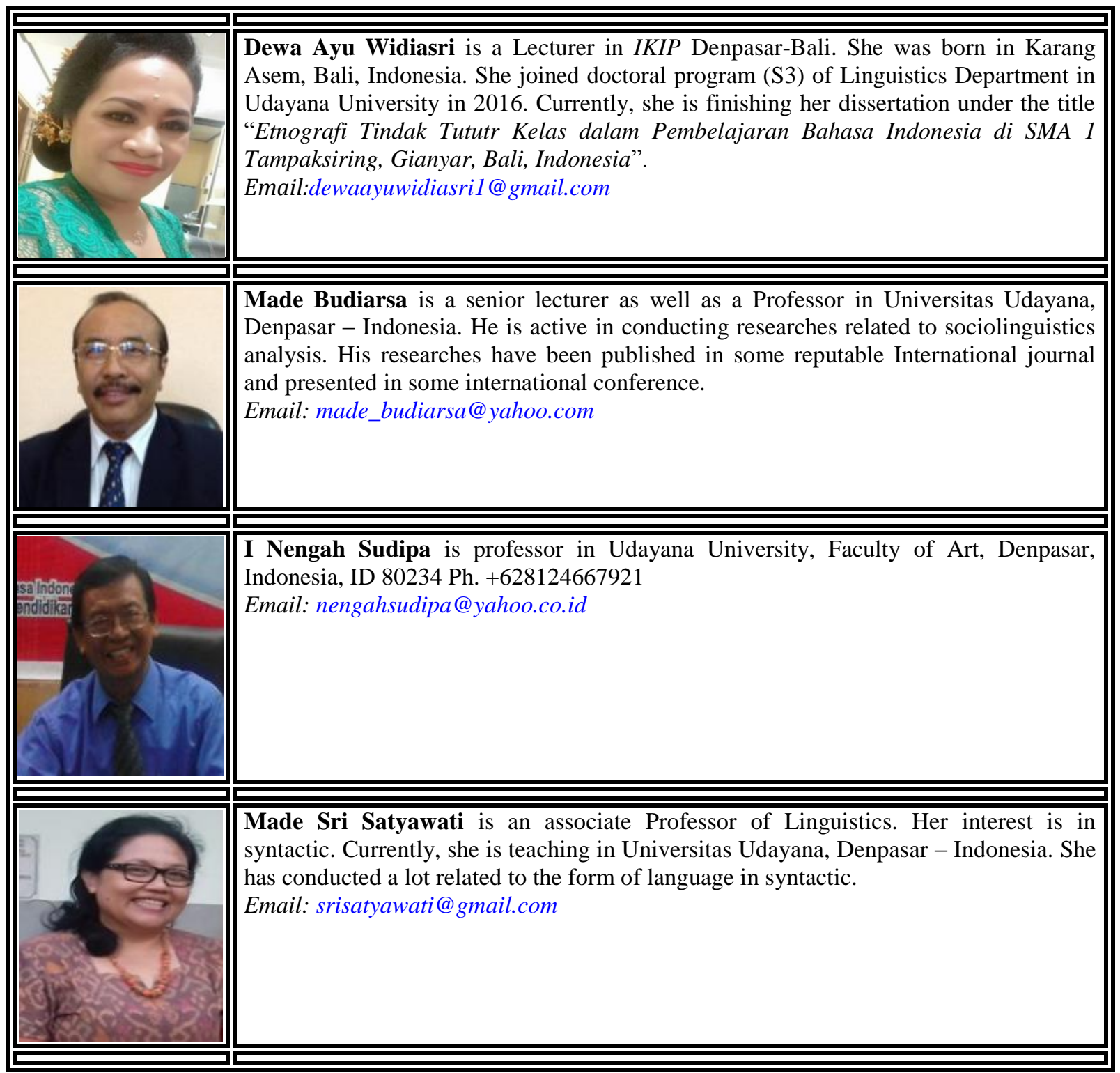

